\title{
The Impact of Debt on Young Family Physicians: Unanswered Questions with Critical Implications
}

\author{
Julie Phillips, MD, MPH
}

In this issue, Bazemore et al demonstrate that $58 \%$ of graduating family medicine residents have more than $\$ 150,000$ of educational debt, and $26 \%$ have more than $\$ 250,000$ debt. ${ }^{1}$ This is important because although the debt levels of graduating US medical students are well documented, little is known about the debt of residents and practicing physicians. Unlike residents-in-training before 2007, the studied residents were not able to defer repayment during their residency training; most entered forbearance and accumulated interest on their loans without a federal subsidy. Most will repay their unsubsidized loans-any amount above $\$ 65,000$ - with an approximately $6 \%$ interest rate; many also have additional federal or private loans with higher rates. ${ }^{2,3}$

Repayment scenarios vary, but the American Association of Medical Colleges estimates that a family physician who graduated in 2012 with $\$ 170,000$ of educational debt, completed a 3-year residency program, and entered forbearance during residency will pay approximately $\$ 3,200$ monthly in standard repayment (over 10 years) and $\$ 1,600$ monthly in extended repayment (over 25 years). Most family physicians will probably choose extended repayment, paying back approximately $\$ 476,000$ over the life of the loans; of this, $\$ 306,000$ will be interest. ${ }^{3}$

From the Sparrow-MSU Family Medicine Residency Program, College of Human Medicine, Michigan State University, East Lansing.

Funding: none.

Conflict of interest: none declared.

Corresponding author: Julie Phillips, MD, MPH, SparrowMSU Family Medicine Residency Program, Michigan State University, 1200 E. Michigan Avenue \# 245, Lansing, MI 48912 (E-mail: Julie.Phillips@hc.msu.edu).

\section{See Related Article on Page 180.}

Some physicians with lower incomes may choose public service loan forgiveness or income-based repayment, but the monthly payment (relative to income) will likely be too high for many, especially during residency training. Those who choose to participate in the National Health Service Corps Loan Repayment Program will receive approximately $\$ 50,000$ with a 2-year, full-time service commitment, reducing their debt but not eliminating it. ${ }^{4}$

Medical education debt has been increasing steadily since medical school became a "loan-dependent, individual investment" in the 1980s. ${ }^{5}$ When students think about how their debt will affect their career choices, they ask residents and recent residency graduates for advice. Debt amounts and repayment terms have changed so rapidly that anyone more senior has had a completely different experience.

\section{High Debt Influences Medical Students to Choose Specialty Careers}

We now have good evidence that debt influences at least some medical students to choose high-income specialties rather than primary care careers. Students with more debt weigh their income potential more heavily when making career plans, and they are more likely to switch their preference for a primary care career to a high-income specialty career over the course of medical school. ${ }^{5}$ In a large, retrospective study of 136,232 physicians, those who had graduated from public schools with more than $\$ 100,000$ of debt (2010 dollars) were less likely to practice family medicine. ${ }^{6}$ In a qualitative study students described their debt as making them feel more cynical, less altruistic, and entitled to a high income. ${ }^{7}$ High debt has also been correlated with callousness, ${ }^{8}$ stress,,${ }^{8,9}$ suicidal thoughts, ${ }^{10}$ failing medical licensing exams, ${ }^{11}$ and leaving or being dismissed from medical school. ${ }^{11}$

As family physicians, we often think of family medicine as an excellent career for students who may have debt but are willing to sacrifice earning a very high 
income. Indeed, a number of survey studies demonstrate that students who choose family medicine value income and "lifestyle" less than their peers. ${ }^{5,12-14}$ The design of these studies reflects our own experience. When we chose to become family physicians, we viewed this as a career that offered economic security, even if it would not support extravagant luxury. But evidence is emerging that some students with high debt do not think of family medicine as a feasible choice for them. ${ }^{7}$ High-income specialization is viewed as the financially secure career path. ${ }^{7}$ This is especially important because people who choose the medical profession value long-term employment and financial stability. ${ }^{15}$

Other students view a family medicine career as feasible, but believe it will offer them fewer choices. For example, they believe they will lose the opportunity to work part-time, support a nonworking spouse, or live in an expensive community. ${ }^{7}$ This student concern is supported by economic analyses projecting the long-term income of young primary care physicians. ${ }^{16,17}$ Thus we are now facing a paradox in the United States: family medicine-the specialty that creates the greatest health value for the nation-is viewed by medical students as the specialty that offers the least personal financial security.

\section{How Will Debt Affect This Generation of Physicians?}

Although student debt has been studied extensively, little is known about how debt will affect the next generation of family medicine residency graduates. Like students, graduating residents with high debt may experience more symptoms of depression ${ }^{18}$; delay marriage, childbearing, and major purchases ${ }^{8}$; or be more likely to regret choosing family medicine. ${ }^{8}$ They may also pursue different career opportunities. The National Health Service Corps and other loan repayment programs may become more attractive, which would improve access to care among underserved populations.

On the other hand, it seems likely that less desirable workforce changes will also occur. More graduates may choose to work as hospitalists, rather than in outpatient primary care. It may become increasingly difficult to recruit family physicians to academic positions or geriatric fellowships, worsening shortages of family physician educators, researchers, and geriatricians. ${ }^{19-21}$ More young family physicians may choose large employers, who typically guarantee early income, rather than starting or joining small practices. ${ }^{22}$ If we do not study the relationship between debt and changes in the workforce, we could easily overlook these changes, or inappropriately attribute them to the different preferences of a new generation.

As the value of family medicine physicians becomes more apparent, additional financial support for family physicians may continue to emerge, such as signing bonuses, loan repayment offers, or higher salaries. According to the Bureau of Labor Statistics, family physician annual salaries have increased over the past 10 years at a rate that outpaces average inflation: from $\$ 138,490$ in 2004 to $\$ 186,320$ in 2014. ${ }^{23}$ Family medicine has been the most recruited medical specialty for nearly a decade. ${ }^{24}$ If debt does not have important life consequences for our newest graduates, it is essential that we continue to educate students about the financial feasibility of a family medicine career. Of course, young family physicians' ability to cope with their debt does not mitigate the unintended consequences of their coping strategies.

\section{Fixing the Income Gap is Essential}

A 2009 analysis from the Robert Graham Center demonstrated that medical students who choose a career in a high-income specialty, rather than primary care, will accumulate an additional $\$ 3.5$ million in income over the course of a lifetime. ${ }^{25}$ Although market-driven increases in family physician income are important, they are insufficient. The gap in payment between primary care and specialty physicians is not primarily the result of a difference in market value. It is caused and sustained by Medicare reimbursement policy, which must be reformed to value primary care in a real way. ${ }^{26,27}$ Until federal physician payment policies are changed, the high income of specialty careers will always be more attractive to medical students, even those with no debt.

But for students and physicians with high debt, the difference in lifetime income between primary care physicians and specialists is personal. Debt forces medical students, residents, and young physicians to make their future income a high priority, regardless of other values, hopes, and dreams.

\section{References}

1. Bazemore A, Peterson L, Jetty A, Wingrove P, Petterson S, Phillips R. Over half of graduating family medicine residents report more than $\$ 150,000$ in educational debt. J Am Board Fam Med 2016;29:180-1. 
2. Federal Student Aid. The U.S. Department of Education offers low-interest loans to eligible students to help cover the cost of college or career school. Washington, DC: United States Department of Education; 2016. Available from: https://studentaid.ed. gov/sa/types/loans/subsidized-unsubsidized\#repaymentplans. Accessed January 15, 2016.

3. Youngclaus J, Fresne J. Physician education debt and the cost to attend medical school. Washington, DC: American Association of Medical Colleges; 2013. Available from: https://www.aamc.org/download/328322/data/ statedebtreport.pdf. Accessed January 16, 2016.

4. NHSC Loan Repayment Program. Washington, DC: National Health Service Corps; 2016. Available from: http://nhsc.hrsa.gov/loanrepayment/ loanrepaymentprogram.html. Accessed January 16, 2016.

5. Grayson MS, Newton DA, Thompson LF. Payback time: the associations of debt and income with medical student career choice. Med Educ 2012;46:983-91.

6. Phillips JP, Petterson SM, Bazemore AW, Phillips RL. A retrospective analysis of the relationship between medical student debt and primary care practice in the United States. Ann Fam Med 2014;12:542-9.

7. Phillips JP, Wilbanks D, Salinas D, Doberneck D. Educational debt in the context of career planning: a qualitative exploration of medical student perceptions. Teach Learn Med. In press.

8. Rohlfing J, Navarro R, Maniya OZ, Hughes BD, Rogalsky DK. Medical student debt and major life choices other than specialty. Med Educ Online 2014; 19:25603.

9. Morra DJ, Regehr G, Ginsburg S. Anticipated debt and financial stress in medical students. Med Teach 2008;30: 313-5.

10. Dyrbye LN, Harper W, Durning SJ, et al. Patterns of distress in US medical students. Med Teach 2011;33: 834-9.

11. Andriole DA, Jeffe DB. Prematriculation variables associated with suboptimal outcomes for the 19941999 cohort of US medical school matriculants. JAMA 2010;304:1212-9.

12. Bennett KL, Phillips JP. Finding, recruiting, and sustaining the future primary care physician workforce: a new theoretical model of specialty choice process. Acad Med 2010;85(10 Suppl):S81-8.

13. Clinite KL, DeZee KJ, Durning SJ, et al. Lifestyle factors and primary care specialty selection: comparing 2012-2013 graduating and matriculating medical students' thoughts on specialty lifestyle. Acad Med 2014;89:1483-9.

14. Teitelbaum HS, Ehrlich N, Travis L. Factors affecting specialty choice among osteopathic medical students. Acad Med 2009;84:718-23.

15. Gillies RA, Warren PR, Messias E, Salazar WH, Wagner PJ, Huff TA. Why a medical career and what makes a good doctor? Beliefs of incoming United States medical students. Educ Health (Abingdon) 2009;22:331.

16. Youngclaus JA, Koehler PA, Kotlikoff LJ, Wiecha JM. Can medical students afford to choose primary care? An economic analysis of physician education debt repayment. Acad Med 2013;88:16-25.

17. Palmeri M, Pipas C, Wadsworth E, Zubkoff $M$. Economic impact of a primary care career: a harsh reality for medical students and the nation. Acad Med 2010;85:1692-7.

18. Dyrbye LN, Thomas MR, Massie FS, et al. Burnout and suicidal ideation among U.S. medical students. Ann Intern Med 2008;149:334-41.

19. Eleazer GP, Brummel-Smith K. Commentary: Aging America: meeting the needs of older Americans and the crisis in geriatrics. Acad Med 2009; 84:542-4.

20. From the Society of Teachers of Family Medicine. STFM launches initiative in response to faculty shortage. Ann Fam Med 2015;13:290-1.

21. Voorhees JR, Xierali IM, Bazemore AW, Phillips RL Jr, Jaen CR, Puffer JC. A small percentage of family physicians report time devoted to research. J Am Board Fam Med 2013;26:7-8.

22. Liaw WR, Jetty A, Petterson SM, Peterson LE, Bazemore AW. Solo and small practices: a vital, diverse part of primary care. Ann Fam Med 2016;14:8-15.

23. Overview of BLS wage data by area and occupation. Washington, DC: Bureau of Labor Statistics, US Department of Labor; 2015. Available from: http://www.bls .gov/bls/blswage.htm. Accessed January 18, 2016.

24. 2014 Review of physician and advanced nurse practitioner recruiting incentives: an overview of the salaries, bonuses, and other incentives customarily used to recruit physicians, physician assistants and nurse practitioners. Irving, TX: Merritt Hawkins; 2014. Available at: http://www. merritthawkins.com/uploadedFiles/MerrittHawkings/ Surveys/mha2014incensurvey.pdf. Accessed January 18, 2016.

25. Phillips RL, Dodoo M, Petterson S, et al. Specialty and geographic distribution of the physician workforce: what influences medical student and resident choices? Washington, DC: Robert Graham Center; 2009. Available at: http://www.graham-center.org/ dam/rgc/documents/publications-reports/monographsbooks/Specialty-geography-compressed.pdf. Accessed January 20, 2016.

26. Bodenheimer T, Matin M, Laing BY. The specialistgeneralist income gap: can we narrow it? J Gen Int Med 2008;23:1539-41.

27. Lasser KE, Woolhandler S, Himmelstein DU. Sources of U.S. physician income: the contribution of government payments to the specialist-generalist income gap. J Gen Int Med 2008;23:1477-81. 